\title{
Report of Carettacola stunkardi (Martin \& Bamberger, 1952) Dailey, Fast \& Balazs, 1991 (Digenea: Spirorchiidae) infecting Green Turtle Chelonia mydas Linnaeus, 1758 (Testudines, Cheloniidae) in Brazil
}

\author{
Werneck, MR. ${ }^{1,2}$, Baldassin, $P{ }^{1}{ }^{1}$, Torres, $F^{3}{ }^{3}$, Trazi, $A .^{3}$ and Berger, $B .^{3}$ \\ ${ }^{1}$ BW Consultoria e Laboratório Veterinário, Rua Ponciano Eugênio Duarte 203, \\ Centro, CEP 11680-000, Ubatuba, SP, Brazil \\ ${ }^{2}$ Centro Universitário Módulo, Av. Frei Pacífico Wagner n. ${ }^{\circ}$ 653, Centro Caraguatatuba, São Paulo, 11660-903, Brazil \\ ${ }^{3}$ Serviços em Meio Ambiente - CTA, Rua Saturnino Rangel Mauro 283, Pontal de Camburi, \\ CEP 29062-030, Vitória, BA, Brazil \\ *e-mail:max@bwvet.com.br
}

Received August 22, 2012 - Accepted September 20, 2012 - Distributed August 31, 2013

The family Spirorchiidae includes approximately 100 species distributed among 19 genera described parasitizing terrestrial and aquatic chelonians (Platt, 2002). Ten of these genera are exclusive to sea turtles (Smith, 1997).

The genus Carettacola was created by Manter and Larson (1950) to house Carettacola bipora. Two other species are currently accepted in this genus: Carettacola stunkardi (Martin \& Bamberger, 1952) Dailey, Fast \& Balazs, 1991 and Carettacola hawaiiensis Dailey, Fast \& Balazs, 1991. All three species are only described parasitizing only sea turtles (Smith, 1997).

The present note report the occurrence of $C$. stunkardi in the green sea turtle Chelonia mydas Linnaeus, 1758 on the northern coast of the Espírito Santo state, Brazil. In September 2011, a C mydas ( $34.5 \mathrm{~cm}$ curved carapace length and $3.25 \mathrm{~kg}$ ) was found at Conceição da Barra Beach $\left(18.40358^{\circ} \mathrm{S}, 39.69339^{\circ} \mathrm{W}\right)$, Espírito Santo state, Brazil. This animal died in a rehabilitation tank and was necropsied. The heart was analyzed based on the method described by Snyder and Clopton (2005) and simplified by Werneck et al. (2006). Only one specimen of $C$. stunkardi was found. The helminth was fixed in alcohol-formalin-acetic acid solution, stained with carmine and cleared with eugenol. The morphometric data were determined with the aid of an image analysis program (ImageJ, National Institutes of Health) The helminth collected were deposited in the Coleção Helmintológica do Instituto de Biociências (CHIBB) of the Universidade Estadual Paulista, Botucatu, São Paulo State, Brazil (Number 151), the parasite analyses were authorized by federal licenses for activities with scientific purposes (SISBIO 30600-1).

The identification key proposed by Platt (2002) and Dailey et al. (1991) was used and morphometric data from the studies of Martin and Bamberger (1951), Caballero et al. (1955) and Werneck et al. (2008) were used to compare our specimen (Table 1).

The characteristics of C. stunkardi specimen: parasite elongate with thin extremities; oral sucker terminal; esophagus sinuous, terminating in a bulb that bifurcates immediately prior to the acetabulum; acetabulum small and not distended; ceca slightly sinuous and extending to the region near the posterior extremity of the body, running ventrally to the vitellaria; seminal vesicle, cirrus sac and ovary located in the anterior third of body; seminal vesicle located after the acetabulum and anterior to the cirrus sac; cirrus sac voluminous, between the ovary and seminal vesicle; ovary with an oval aspect; testis with round or slightly flattened shape, in the intra-cecal position and extending from the ovary region to near the excretory vesicle at the posterior extremity of the body vitellaria composed of groups of follicles ex- tending dorsally to the ceca from the posterior region to near the ovary; excretory vesicle Y shaped. No eggs were found.

The genus Carettacola was created in 1950 to house $C$. bipora, which was found parasitizing the intestine of the sea turtle Caretta caretta Linnaeus, 1758, in the state of Florida, USA (Manter and Larson, 1950).

After, Martin and Bamberger (1952) described the genus Haemoxenicon in the sea turtle C. mydas in the state of California, USA, with two new species found in the mesenteric vessels: $H$. stunkardi and $H$. chelonenecon.

Caballero et al. (1955) reported H. stunkardi in blood vessels of the urinary bladder in C. mydas in Panama. Analyzing the specimens encountered, the authors determined (due to the compression process) that $H$. stunkardi and $H$. chelonenecon were actually the same species and maintained the former name as valid.

The genera Carettacola and Haemoxenicon remained separate until 1995, when Dailey, Fast \& Balazs analyzed C. bipora and $H$. stunkardi deposited in collections, defined the similarity between the genera and classified Haemoxenicon as a junior synonym of Carettacola. In the same paper, the authors described the species $C$. hawaiiensis found in blood vessels of the liver in individuals of C. mydas from the state of Hawaii, USA.

Carettacola stunkardi has found in C. mydas in the United States (Martin and Bamberguer, 1952) and Panama (Caballero et al., 1955) and in a juvenile of Eretmochelys imbricata Linnaeus, 1758 in Brazil (Werneck et al., 2008).

The morphometric findings (Table 1) are within the ranges described in previous studies, except for the larger length and width of the oral sucker, smaller width of the ovary and smaller number of testicles. These findings do not render the identification of the species unviable and contribute toward the identification of morphometric variations in the species.

In 2011, the hearts of 12 juvenile individuals of $C$. mydas from the northern coast of the Espírito Santo State, Brazil were analyzed and C. stunkardi was only found in one (prevalence: $8.33 \%$ ). There are no reports on the prevalence rate of $C$. stunkardi. However, Werneck (2011) analyzed 31 individuals of E. imbricata from the coast of Brazil and found only two specimens in one host (prevalence: $3.2 \%$ ). These data and other reports on C. stunkardi allow one to suppose that the prevalence of this helminth is low.

There are few papers on the occurrence of the family Spirorchiidae in Brazil, with only six species reported: Learedius learedi Price, 1934 (Werneck et al., 2006), Monticellius indicum Mehra, 1939 (Werneck et al., 2008b) and Amphiorchis indicus Mehrotra, 1973 (Werneck and 
Werneck, MR.

Table 1 - Morphometric data, in millimeters, of Carettacola stunkardi (Martin \& Bamberger, 1952) Dailey, Fast \& Balazs, 1991 (Digenea: Spirorchiidae) from marine turtles.

\begin{tabular}{|c|c|c|c|c|}
\hline Variable & $\begin{array}{c}\text { Martin \& Bamberger } \\
\text { (1951) }\end{array}$ & $\begin{array}{l}\text { Caballero et al. } \\
\text { (1955) }\end{array}$ & $\begin{array}{c}\text { Werneck et al. } \\
\text { (2008) }\end{array}$ & Present report \\
\hline Host & C. mydas & C. mydas & E. imbricata & C. mydas \\
\hline Site of infection & Mesenteric veins & $\begin{array}{l}\text { Blood vessels of the } \\
\text { urinary bladder }\end{array}$ & Body wash & Heart \\
\hline Locality & USA & Panamá & Brazil & Brazil \\
\hline Number of parasites & $4(5$ colected $)$ & $6(9$ colected $)$ & 1 & 1 \\
\hline Body length & $3.34-3.88$ & $4.648-5.246$ & 6.504 & 4.65 \\
\hline Body width & $0.3-0.36$ & 0.349 & 0.469 & 0.44 \\
\hline Oral sucker length & 0.083 diâmetro & $0.099-0.137$ & 0.100 & 0.16 \\
\hline Oral sucker width & & $0.106-0.122$ & 0.091 & 0.14 \\
\hline Acetabulum & 0.15 (diameter) & $\begin{array}{c}0.106-0.133 x \\
0.118-0.182\end{array}$ & 0.2 (diameter) & 0.16 (diameter) \\
\hline Ovary length & 0.17 & $0.213-0.266$ & 0.33 & 0.2 \\
\hline Ovary width & 0.21 & $0.114-0.122$ & 0.241 & 0.1 \\
\hline Number of testes & $35-46$ & $39-40$ & 39 & 29 \\
\hline Testes length & $0.036-0.14$ & 0.099-0.106 & 0.212 & $0.05(0.04-0.06)$ \\
\hline Testes width & $0.024-0.095$ & $0.114-0.129$ & 0.154 & $0.09(0.08-0.11)$ \\
\hline
\end{tabular}

Silva, 2013) in juvenile of C. mydas; Amphiorchis solus (Simha \& Chattopadhyaya, 1970) in adult of C. mydas (Werneck et al., 2011); and C. stunkardi and Amphiorchis caborojoensis Fischthal \& Acholonu, 1976 in E. imbricata (Werneck et al., 2008a).

The present note reports the fourth occurrence of $C$. stunkardi in the world, the second in sea turtles on the Brazilian coast and the first time in C. mydas in the same region.

Acknowledgments - The biological samples were obtained through the Beach Monitoring Project of the state of Espírito Santo and northern portion of the Campos Basin, which is a requirement established by the federal environmental licensing division of the Brazilian environmental agency IBAMA.

\section{References}

CABALLERO, CE., ZERECERO MC. and GROCOTT RG., 1955. Helmintos de la República de Panamá. XI. Tremátodos de Chelonia mydas (L) tortuga marina comestible del Océano Pacífico del norte. $2^{\mathrm{a}}$ parte. Anales del Instituto de Biologia Universidad Nacional Autónoma de México, vol. 26, no. 1, p. 149-191.

DAILEY, MD., FAST, ML. and BALAZS, GH., 1991. Carettacola hawaiiensis N. SP. (Trematoda: Spirorchiidae) from the green turtle, Chelonia mydas, in Hawaii. Journal of Parasitoloy, vol. 77, no. 6, p. 906-909.

MANTER, HW. and LARSON, M., 1950. Two new blood flukes from marine turtle, Caretta caretta. Journal of Parasitology, vol.36, p.595-599.

MARTIN, WE. and BAMBERGER, JW., 1952. New blood flukes (Trematoda: Spirochiidae) from the marine turtle, Chelonia mydas (L.). Journal of Parasitology, vol. 38, p.105-110.

PLATT, TR., 2002. Family spirorchiidae Stunkard. In Gibson, DI., Jones, A. and Bray, RA. (Eds.). Keys to the Trematoda. London: CABI Publishing. p. 453-467.
SMITH, JW., 1997. The blood flukes (Digenea: Sanguinicolidae and Spirorchiidae) of cold-blooded vertebrates: part. 2 . Helminthological Abstracts, vol. 6, no. 10, p. 329-344.

SNYDER, S. and CLOPTON, R., 2005. New methods for the collection and preservation of spirorchiid trematodes and Polystomatid manogeneus from turtles. Comparative Parasitology, vol. 72, no. 1, p. 102-107.

WERNECK, MR., 2011. Estudo da helmintofauna de tartarugas marinhas procedentes da costa brasileira. Botucatu: Universidade Estadual Paulista. Tese de doutorado em Biologia Geral e Aplicada.

WERNECK, MR. and SILVA, RJ., 2013. Occurrence of Amphiorchis indicus Mehrotra, 1973 (Digenea, Spirorchiidae) infecting Green Turtle Chelonia mydas Linnaeus, 1758 (Testudines, Cheloniidae) in Brazil. Brazilian Journal of Biology, in press.

WERNECK, MR., BECKER, JH. GALLO, BMG. and SILVA, RJ , 2006. Learedius learedi Price 1934 (Digenea, Spirorchiidae) in Chelonia mydas Linnaeus 1758 (Testudines, Chelonidae) in Brazil: case report. Arquivo Brasileiro de Medicina Veterinária e Zootecnia, vol. 58, no. 4, p. 550-555.

WERNECK, MR., GALLO, BMG. and SILVA RJ., 2008b. Spirorchiids (Digenea: Spirorchiidae) infecting a Hawksbill sea turtle Eretmochelys imbricata (Linnaeus 1758) from Brazil. Arquivo Brasileiro de Medicina Veterinária e Zootecnia, vol. 60, no. 3, p. 663-666.

WERNECK, MR., GALLO BMG. and SILVA RJ., 2008a. First report of Monticellius indicum Mehra, 1939 (Digenea: Spirorchiidae) infecting Chelonia mydas Linnaeus, 1758 (Testudines: Chelonidae) from Brazil. Brazilian Journal of Biology, vol. 68, no. 2, p. 455-456.

WERNECK, MR., GALLO, B., LIMA, EHDM. and SILVA, RJ., 2011. Occurrence of Amphiorchis solus Simha \& Chattopadhyaya, 1970 (Digenea, Spirorchiidae) infecting Green turtle Chelonia mydas Linnaeus, 1758 (Testudines, Cheloniidae) in Brazil. Comparative Parasitology, vol. 78, no. 1 , p. 200-203. 